\title{
AGUADAS PARA GANADERÍA BOVINA EN LOS BAJOS SUBMERIDIONALES Y ÁREAS DE INFLUENCIA
}

\author{
BASAN NickisCh, M. ${ }^{1 ;}$ LAHITTE, A. 2; SOSA, D. ${ }^{3 ;}$ \\ SANCHEZ, L. ${ }^{1} \&$ TOSOLINI, R. ${ }^{4}$
}

\begin{abstract}
RESUMEN
En el norte de la provincia de Santa Fe, especialmente en la Cuña Boscosa, Bajos Submeridionales y Domo Occidental, se encuentran más de tres millones de cabezas de ganado vacuno, donde uno de los principales condicionantes en la producción es la irregular calidad del agua subterránea para el abrevado de la hacienda. La fluctuación entre escenarios hidrológicos secos y húmedos repercute directamente en la producción, donde no solo varía el nivel freático del acuífero libre, único aprovechable, sino fundamentalmente la calidad química del agua. El INTA, articulando con el INA, con el Gobierno de Santa Fe y con Centros de Estudio de la UNL, ha concretado unidades demostrativas de investigación y transferencia en campos de productores y unidades experimentales de la Institución, diseñando y proponiendo distintas tecnologías consensuadas con los productores en lo que hace al manejo del agua de lluvia complementada con la subterránea. 3 Sistemas de Aguadas se concretaron con diferentes maneras de aprovechar el agua de lluvia con el agua subterránea, sistematizando terrenos para garantizar el acceso y recarga del acuífero libre, con mecanismos de bombeo mediante energía renovable y con sistemas de succión que lo hacen en la parte superficial del acuífero, donde todos convergen a un tanque central de mezcla, para garantizar así que todos los animales tomen agua con la misma calidad química, cualquiera sea el lugar de pastaje. Desde el año 2011 se monitorean las variables de interés, donde la premisa es tener controlada la salinidad del agua en el tanque central de mezcla y que sus variaciones a través del año sean graduales, ya que esto maximiza la producción ganadera. Esto se visualiza en cada uno de los 3 sistemas y, fundamentalmente en el tanque central de mezcla, donde la cantidad, calidad y oportunidad durante el año evidencian claramente resultados muy positivos en el lugar estudiado.
\end{abstract}

Palabras clave: esponjas vaginales, adherencias, tetraciclina, corticoide.

1.- INTA EEA Reconquista. Ruta aAcional $N^{\circ} 11$ - Km 773. (3560) Reconquista, provincia de Santa Fe. Email: basannickisch.mario@inta.gob.ar

2.- Productor pecuario y Consejero Directivo de INTA.

3.- INA - CRL

4.- INTA EEA Rafaela.

Manuscrito recibido el 6 de sebtiembre de 2016 v aceptado para su publicación el 7 de diciembre de 2016. 


\begin{abstract}
Water for livestock cattle in the lower submeridional and areas of influence. In the north of the province of Santa Fe, especially in the forest wedge, Lower Submeridionals and Occidental Domo, there are more than three million head of cattle, where one of the main determinants of production is the irregular quality of groundwater For the watering of the hacienda. Thefluctuationbetween dry and wethydrological scenarioshas a directimpactonproduction, wherenot onlythefreewatertable, whichistheonlyavailablewater, varies, butalsothechemicalquality ofthewater. In collaboration with the INA, the Government of Santa Fe and UNL Research Centers, INTA has developed research and transfer demonstration units in the fields of producers and experimental units of the Institution, designing and proposing different technologies that are consensual with the Producers in the management of rainwater supplemented with the underground. 3 water systems were implemented with different ways of using rainwater with groundwater, systematizing terrain to guarantee access and recharge of the free aquifer, with pumping mechanisms using renewable energy and with suction systems that do it in the part Surface of the aquifer, where all converge to a central mixing tank, to ensure that all animals take water with the same chemical quality, whatever the place of grazing. Since 2011 the variables of interest are monitored, where the premise is to have controlled the salinity of the water in the central mixing tank and that its variations throughout the year are gradual, since this maximizes livestock production. This is visualized in each of the three systems and, fundamentally in the central mixing tank, where the quantity, quality and opportunity during the year clearly show very positive results in the place studied.
\end{abstract}

Key words: water for animal consumption, water quality, management of water, storage, appropriate technologies.

\section{OBJETIVO}

El objetivo central de este trabajo es analizar la evolución de la calidad química del agua para abrevado de ganadería de cría bovina que se obtiene a partir de las innovaciones tecnológicas incorporadas en cada una de las aguadas que componen el sistema de aprovisionamiento del Establecimiento Ganadero "La Güeya”, Tostado, Provincia de Santa Fe, y proponer alternativas superadoras para el futuro.

\section{MATERIALES Y MÉTODOS}

Se analizaron tres sistemas de aprovisionamiento de agua para el ganado en el Establecimiento "La Güeya”: A, B y C y la calidad del agua obtenida en el Tanque Central de mezcla.

El sistema A ha sido diseñado para complementar los módulos preexistentes B y C. Los tres poseen diferentes técnicas de recarga con agua de lluvia para aprovechar el agua subterránea del acuífero libre, habiéndose evaluado la interrelación de la salinidad del agua de la fuente subterránea con el nivel dinámico de bombeo, con la pre- 